\title{
ANALISIS PRODUKSI CABAI SKALA USAHA MIKRO DI KABUPATEN KEPAHIANG
}

\author{
Irfan Dani ${ }^{1)}$, Retno A Ekaputri ${ }^{2)}$ \\ ${ }^{1}$ Jurusan Ekonomi Pembangunan Fakultas Ekonomi Dan Bisnis Universitas Bengkulu \\ Email: irfandani30@gmail.com \\ 2 Jurusan Ekonomi Pembangunan Fakultas Ekonomi Dan Bisnis Universitas Bengkulu \\ Email: retnoae@unib.ac.id
}

\begin{abstract}
The aim of this research is to find out the influence of chili prices, chili production in the previous year, land area, price of leek on the chili supply in Kepahiang regency. This study covers the period 2004-2018, using secondary data in the form of panel data which is analyzed using multiple linear regression and the existing data is processed using the Eviews 9.0 computer program. The results of data analysis showed that the independent variable was the price of chili, the previous year's chili production and the area of land were positive and had a significant influence on the dependent variable that is chili production. While the price of scallion has a negative coefficient value and does not have a significant influence on chili production in Kepahiang regency.
\end{abstract}

Keywords: Chili Prices, Chili Production, Land Area, Previous Year's Chili Production, Price Scallion.

\section{PENDAHULUAN}

Indonesia sebagai negara sedang berkembang berusaha meningkatkan pembangunan di segala bidang, tidak terkecuali pada sektor pertanian. Indonesia merupakan negara tropis yang memiliki lahan pertanian yang sangat luas sehingga usaha di bidang pertanian sangat baik untuk dikembangkan, baik budidaya tanaman pangan maupun hortikultura. Keadaan iklim yang mendukung dan prospek peluang agribisnis yang baik mendorong komoditas sayuran banyak dikembangkan oleh masyarakat, terutama komoditas cabai yang memiliki nilai ekonomis cukup tinggi. Usaha tani cabai memiliki peluang yang potensial untuk dikembangkan karena dapat menaikkan pendapatan petani, sebagai bahan baku industri, berpeluang sebagai komoditas ekspor serta dapat menyerap tenaga kerja (Agromedia, 2010).

Dalam penelitian (Ariyani, 2016), tanaman hortikultura merupakan tanaman yang paling banyak dibudidayakan oleh petani di Indonesia, karena produk hortikultura merupakan bahan pangan yang dibutuhkan manusia untuk kehidupan sehari-hari. Tanaman yang termasuk dalam tanaman hortikultura yaitu, tanaman sayur-sayuran, buah-buahan dan tanaman hias. Sayuran merupakan salah satu bahan pangan yang berfungsi sebagai salah satu sumber gizi. Kebutuhan sayuran bagi masyarakat semakin meningkat seiring dengan bertambahnya jumlah penduduk.

Cabai (Capsicum annum L), merupakan salah satu sayuran yang permintaannya cukup tinggi, baik untuk pasar domestik maupun ekspor ke mancanegara, seperti Malaysia, dan Singapura (Sembiring, 2009). Selama ini dikenal tiga jenis cabai, yakni cabai merah besar, cabai rawit dan cabai merah keriting. Sebagian besar penduduk Indonesia mengonsumsi cabai dalam bentuk segar, kering atau olahan. Cabai termasuk komoditas unggulan nasional dan sumber vitamin c (Duriat, 1995). Daerah penanamannya luas karena dapat diusahakan di dataran rendah maupun dataran tinggi, sehingga banyak petani di Indonesia yang menanam cabai (Kusandriani 1996; Ameriana et al. 1998). 
Cabai merupakan salah satu jenis sayuran yang sangat penting karena memiliki nilai ekonomi yang tinggi. Cabai digunakan di bidang kuliner baik dalam bentuk cabai segar maupun olahan. Siklus kebutuhan cabai di Indonesia meningkat menjelang bulan-bulan tertentu, seperti memasuki bulan puasa, lebaran, natal dan tahun baru. Permintaan cabai yang tinggi diikuti dengan harga yang melambung (Redaksi Agromedia, 2008).

Provinsi Bengkulu telah mengembangkan berbagai macam tanaman hortikultura. Tanaman cabai merupakan salah satu komoditi hortikultura yang permintaannya semakin meningkat. Selain mempunyai nilai ekonomis, tanaman cabai juga dapat tumbuh dengan baik pada daerah dataran rendah hingga daerah dataran tinggi. Dalam pengusahaannya petani tidak hanya bertujuan untuk memenuhi kebutuhan rumah tangga saja tetapi sebagai sumber pendapatan keluarga (BPS, 2017).

Tanaman hortikultura di kabupaten Kepahiang meliputi bawang merah, cabai, kentang, kubis, tomat dan daun bawang. Cabai merupakan komuditas dengan lahan terluas diantara komuditas sayuran lainnya yang terdapat di Provinsi Bengkulu. Kabupaten Rejang Lebong merupakan pemilik lahan terluas untuk komoditas cabai dengan luas lahan mencapai 3.282 Ha. Sementara itu, Kabupaten Kepahiang berada pada posisi terbesar kedua luas panen komuditas cabai di Provinsi Bengkulu dengan luas sebesar $330 \mathrm{Ha}$. Luas panen terkecil usaha tani cabai ialah di Kota Bengkulu dengan luas panen hanya mencapai 20 Ha saja di tahun 2016 (BPS 2017).

Menurut Badan Pusat Statistik (2018), Dalam perbandingan tingkat produktivitas tanaman cabai di setiap kabupaten/kota yang ada di Provinsi Bengkulu selama lima tahun terakhir, Kabupaten Kepahiang menempati posisi tertinggi tingkat produktivitas cabai diantara kabupaten/kota yang ada di Provinsi Bengkulu dengan rincian pada tahun 2013 sebesar 130,23 kwintal/ha, tahun 2014 sebesar 125,26 kwintal/ha, sedangkan pada tahun 2015 sebesar 108,07 kwintal/ha, tahun 2016 sebesar 79,22 kwintal/ha, dan di tahun 2017 sebesar 60,92 kwintal/ha.

Luas panen terbesar tanaman sayuran di kecamatan yang ada di Kabupaten Kepahiang adalah tanaman komoditas cabai dengan luas panen mencapai 223 Ha. Sedangkan luas panen terkecil adalah tanaman bawang merah dengan luas hanya sebesar 1 Ha saja. Luas panen komoditas cabai di Kabupaten Kepahiang terbesar terdapat di Kecamatan Kabawetan sebesar 85 Ha (Badan Pusat Statistik, 2018).

Produksi cabai dari tahun 2006 sampai dengan 2015 mengalami fluktuasi disetiap tahunnya. Dari tahun 2006, 2007 hingga 2008 produksi cabai meningkat dari 2.689 ton menjadi 3.148 kemudian meningkat menjadi 3.513 ton, dengan perubahan luas panen dari 820 hektar naik menjadi 919 hektar kemudian meningkat menjadi 1463 hektar. Kemudian mengalami penurunan jumlah produksi di tahun 2009 hingga 3.157 ton dengan luas panen 574 hektar dan kembali meningkat di tahun 2010 hingga 2011 sebesar 4.582 ton dengan luas panen yang semakin meluas mencapai 811 hektar. Produksi cabai di Kabupaten Kepahiang kembali mengalami penurunan jumlah produksi di tahun 2012 sebesar 3.551 ton dengan luas panen seluas 311 hektar dan mengalami peningkatan di tahun 2013 menjadi 5.453 ton diikuti dengan perluasan luas panen sebesar 413 hektar, kemudian kembali mengalami penurunan di tahun 2014 hingga 2017 hingga mencapai 4809 ton dengan luas panen 223 hektar.

Permintaan pasar (konsumen) terhadap produk cabai cenderung terus meningkat dari waktu ke waktu sejalan dengan meningkatnya konsumsi cabai di berbagai daerah. Sekalipun ada kecenderungan peningkatan kebutuhan, tetapi permintaan terhadap cabai untuk kebutuhan seharihari dapat berfluktuasi, yang disebabkan karena naik turunnya harga cabai di pasaran. Fluktuasi harga yang terjadi di pasaran, selain disebabkan oleh faktor-faktor yang mempengaruhi sisi permintaan juga disebabkan oleh faktor-faktor yang mempengaruhi sisi penawaran. Dari sisi penawaran menunjukkan bahwa proses penyediaan (produksi dan distribusinya) cabai belum sepenuhnya dikuasai para petani. Faktor utama yang menjadi penyebab adalah petani cabai adalah 
petani kecil-kecil yang proses pengambilan keputusan prduksinya diduga tidak ditangani dan ditunjang dengan suatu peramalan produksi dan harga yang baik (Unila, 2011).

Tabel 1 Perkembangan Harga Cabai di Kabupaten Kepahiang Tahun 2012 - 2016

\begin{tabular}{lll}
\hline No & Tahun & Harga $(\mathbf{R p})$ \\
\hline 1. & 2012 & $30.250,54$ \\
2. & 2013 & $34.265,89$ \\
3. & 2014 & $25.657,33$ \\
4. & 2015 & $32.150,21$ \\
5. & 2016 & $20.103,74$ \\
\hline
\end{tabular}

Sumber : Dinas Ketahanan Pangan dan Perikanan Kabupaten Kepahiang, 2018

Dari Tabel 1 menunjukkan fluktuasi rata-rata harga cabai di Kabupaten Kepahiang dari tahun 2012 hingga 2016 mengalami fluktuasi harga yang cukup bervariasi. Pada tahun 2012 rata-rata harga cabai di Kabupaten Kepahiang sebesar 30.250,54 rupiah kemudian mengalami kenaikan harga sebesar 34.265,89 rupiah di tahun 2013. Pada tahun 2014 harga rata-rata cabai di Kabupaten Kepahiang mengalami penurunan sebesar 25.657,33 rupiah dan kembali mengalami kenaikan di tahun 2015 sebesar 32.150,21 rupiah. Pada tahun 2016 harga rata-rata cabai di Kabupaten Kepahiang mengalami penurunan yang cukup signifikan menjadi 20.103,74 rupiah.

Dari latar belakang yang telah dijelaskan, meskipun Kabupaten Kepahiang menempati posisi kedua luas panen terbesar setelah kabupaten rejang lebong, akan tetapi menurut data Badan Pusat Statistik Provinsi Bengkulu tingkat produktivitas cabai di Kabupaten Kepahiang lebih tinggi dibandingkan dengan kabupaten Rejang Lebong dan kabupaten lainnya. Kemudian, luas panen tanaman sayuran di Kabupaten Kepahiang terbesar adalah usaha tani cabai dibandingkan dengan luas panen komoditas sayuran lainnya yang ada di setiap kecamatan di Kabupaten Kepahiang.

Terjadinya perubahan jumlah produksi, luas areal panen dan tingkat harga akan berpengaruh terhadap penawaran. Dengan adanya fluktuasi luas lahan dan jumlah produksi cabai di setiap tahunnya dengan harga yang bervariasi menggugah keingintahuan peneliti lebih lanjut sehingga peneliti bermaksud untuk mengetahui lebih jauh mengenai respon penawaran cabai yang ada di Kabupaten Kepahiang. Kemudian akses lokasi objek penelitian juga merupakan kabupaten tempat tinggal peneliti, sehingga memudahkan peneliti dalam memperoleh data yang lebih akurat. Adapun judul penelitian ini adalah "Analisis Faktor yang Mempengaruhi Penawaran Cabai di Kabupaten Kepahiang".

\section{LANDASAN TEORI}

\section{Penawaran}

Penawaran (supply) mempunyai arti jumlah dari suatu barang tertentu yang akan dijual pada berbagai kemungkinan harga, dalam jangka waktu tertentu, ceteris paribus. Penawaran (supply) menunjukkan jumlah (maksimum) yang akan dijual pada berbagai tingkat harga atau beberapa harga (minimum) yang masih mendorong penjual untuk menawarkan berbagai jumlah suatu barang (Hanafie, 2010 : 117).

Penawaran adalah jumlah barang yang produsen ingin tawarkan (jual) pada berbagai tingkat harga selama satu periode tertentu. Perubahan harga akan menyebabkan perubahan jumlah yang ditawarkan. Jika yang berubah adalah faktor non harga (faktor-faktor yang dianggap cateris paribus ketika harga barang itu berubah), maka kurva penawaran bergeser ke kiri atau ke kanan. Bergeser ke kanan berarti jumlah yang lebih banyak akan ditawarkan pada sembarang harga yang 
tetap, dan bergeser ke kiri berarti jumlah yang lebih sedikit akan ditawarkan pada harga yang tetap mana pun (Rahardja dan Manurung, 2010).

Hukum penawaran merupakan suatu dalil/rumusan yang menerangkan hubungan antara tingkat harga dan kuantitas barang yang ditawarkan. Hubungan tersebut adalah semakin tinggi harga suatu barang maka semakin banyak kuantitas yang ditawarkan. Sebaliknya, jika semakin rendah harga suatu barang, maka semakin sedikit jumlah barang yang ditawarkan. Secara grafis hubungan ini dapat digambarkan oleh kurva penawaran (Sukirno, 2006). Kurva penawaran memperlihatkan apa yang terjadi dengan kuantitas barang yang ditawarkan ketika harganya berubah dengan menganggap seluruh faktor penentu lainnya konstan. Jika satu dari faktor-faktor tersebut berubah, kurva penawaran akan bergeser (Mankiw, 2000).

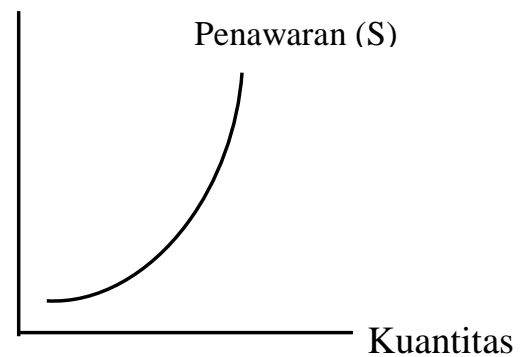

Gambar 1 Kurva Penawaran

Kurva penawaran dapat didefinisikan sebagai suatu kurva yang menggambarkan hubungan antara harga suatu barang tertentu dengan jumlah barang tersebut yang ditawarkan para produsen. Perubahan harga yang terjadi menyebabkan perubahan harga yang ditawarkan, tetapi perubahan itu hanya terjadi dalam satu kurva yang sama. Sedangkan kurva penawaran akan bergeser ke kanan atau ke kiri jika terdapat perubahan penawaran yang ditimbulkan oleh faktor-faktor bukan harga. Kurva penawaran yang bergeser ke sebelah kanan menunjukan terjadinya pertambahan dalam penawaran, sebaliknya pergeseran kurva penawaran ke sebelah kiri berarti bahwa penawaran telah berkurang (Firdaus, 2008).

Menurut Haryati (2007), kurva penawaran adalah kurva yang menghubungkan titik-titik kombinasi antara harga dengan jumlah barang yang diproduksi atau ditawarkan. Kurva penawaran merupakan garis pembatas jumlah barang yang ditawarkan pada tingkat harga tertentu. Pergeseran kurva menunjukkan adanya pergeseran keseluruhan kurva penawaran. Ini mengandung arti adanya perubahan dalam jumlah yang ditawarkan pada tiap tingkat harga produk. Perpindahan sepanjang kurva menunjukkan adanya perubahan jumlah yang ditawarkan sebagai respon atas terjadinya perubahan harga produk.

Fungsi penawaran adalah suatu fungsi yang menyatakan hubungan antara produksi yang ditawarkan dengan harga, menganggap faktor lain sebagai teknologi dan harga input yang digunakan adalah tetap. Penawaran individu adalah penawaran yang disediakan oleh individu produsen, diperoleh dari produksi yang dihasilkan. Besarnya jumlah produksi yang ditawarkan ini akan sama dengan jumlah permintaan, sedangkan penawaran agregat ini merupakan jumlah penawaran individu (Soekartawi, 1993).

\section{Cabai}

Kusandriani (1996) menganalisa tentang sejarah cabai, dimana cabai awalnya berasal dari Mexico. Sebelum abad ke-15 spesies ini lebih banyak dikenal di Amerika Tengah dan Selatan. Sekitar 
tahun 1513 Columbus membawa dan menyebarkan cabai dan diperkirakan masuk ke Indonesia melalui pedagang dari Persia ketika singgah di Aceh.

Pemaparan mengenai cabai juga dikemukakan oleh Susanti (2006) yang menyebutkan bahwa cabai merupakan salah satu jenis sayuran yang banyak mengandung vitamin khususnya vitamin C. Cabai merupakan salah satu komoditas sayuran (hortikultura) yang banyak digemari masyarakat Indonesia dan mempunyai nilai ekonomi tinggi. Sesuai dengan namanya, cabai memiliki warna kulit buah yang merah sewaktu buah sudah tua dan masak. Bentuk buahnya silindris dan mengecil ke arah ujung buah. Ciri dari jenis sayuran ini rasanya pedas dan aromanya yang khas. Cabai dapat digunakan dengan cara dimasak atau dikonsumsi mentah, selain itu jenis sayuran yang satu ini bagi orang-orang tertentu dapat membangkitkan selera makan.

Cabai (Capsicum annum L) merupakan salah satu komoditi hortikultura yang mempunyai peranan penting dalam kehidupan manusia, karena selain sebagai penghasil gizi, juga sebagai bahan campuran makanan dan obat-obatan. Tanaman cabai mempunyai nilai ekonomis penting dan menduduki tempat kedua setelah kacang-kacangan (Rompas,2001).

\section{Luas Lahan}

Lahan adalah tanah yang digunakan untuk usaha pertanian. Penggunaan lahan sangat tergantung pada keadaan dan lingkungan lahan berada (Daniel, 2004). Struktur tanah yang baik untuk pertanaman cabai adalah tanah yang gembur sehingga aerasi udara dan perakaran berkembang sempurna, oleh karena itu upaya pemecahan bongkahan tanah atau agregat tanah menjadi partikelpartikel kecil akan memudahkan akar menerobos.

Tanah merupakan faktor terpenting dalam pertanian karena tanah merupakan tempat dimana usaha tani dapat dilakukan dan tempat hasil produksi dikeluarkan karena tanah tempat tumbuh tanaman. Tanah memiliki sifat tidak sama dengan faktor produksi lain yaitu luas relatif tetap dan permintaan akan lahan semakin meningkat sehingga sifatnya langka (Mubyarto, 1989: 89). Luas lahan juga memberi dampak upaya transfer dan teknologi dalam pembangunan pertanian (Moehar Daniel, 2002: 58).

\section{Produksi Cabai}

Produksi secara teknis adalah suatu proses pendayagunaan sumber sumber yang tersedia dengan harapan akan mendapatkan hasil yang lebih dari segala pengorbanan yang telah diberikan. Produksi dalam arti ekonomi mempunyai pengertian semua kegiatan yang meningkatkan nilai kegunaan atau faedah (utility) suatu benda. Ini dapat merupakan kegiatan yang meningkatkan kegunaan dengan mengubah bentuk atau menghasilkan barang baru (utility form). Dapat pula meningkatnya kegunaan suatu benda itu karena ada kegiatan yang mengakibatkan dapat berpindahnya pemilikan suatu benda dari tangan seseorang ke tangan orang lain (Sriyadi, 2001: 6)

Sedangkan menurut Bruce R. Beattie diterjemahkan Dr Soeratno Josohardjono (1994: 3), produksi yaitu proses kombinasi dan koordinasi material- material dan kekuatan-kekuatan (input, faktor, sumberdaya, atau jasa-jasa) produksi dalam pembuatan suatu barang/jasa (output atau produk).

\section{Harga}

Swastha (2001) mendefinisikan harga sebagai sejumlah uang (ditambah beberapa produk) yang dibutuhkan untuk mendapatkan sejumlah kombinasi dari produk dan pelayanannya. Dari definisi diatas dapat diketahui bahwa harga yang dibayar oleh pembeli sudah termasuk layanan yang diberikan oleh penjual. Banyak perusahaan mengadakan pendekatan terhadap penentuan harga berdasarkan tujuan yang hendak dicapainya. Adapun tujuan tersebut dapat berupa meningkatkan 
penjualan, mempertahankan market share, mempertahankan stabilitas harga, mencapai laba maksimum dan sebagainya.

Harga adalah apa yang harus di berikan oleh konsumen (pembeli) untuk mendapatkan suatu produk (Lamb at All, 2001). Salah satu gejala ekonomi yang sangat penting dan berhubungan dengan prilaku petani baik sebagai produsen maupun sebagai konsumen adalah harga (Mubyarto, 1994). Dalam arti yang paling sempit, harga (price) adalah jumlah uang yang akan di bebankan atas suatu produk atau jasa. Lebih luas lagi, harga adalah jumlah dari seluruh nilai yang ditukar konsumen atas manfaat-manfaat memiliki atau menggunakan produk atau jasa tersebut (Kotler dan Armstrong, 1999).

\section{METODE PENELITIAN}

Jenis penelitian ini adalah penelitan deskriptif kuantitatif. Data yang digunakan dalam penelitian ini merupakan data time series dan cross section selama kurun waktu lima belas tahun mulai dari tahun 2004 sampai dengan 2018 di delapan kecamatan. Jenis data yang digunakan adalah sekunder yang bersumber dari instansi yang berkaitan dengan penelitian ini diantaranya Badan Pusat Statistik dan Dinas Pertanian Kabupaten Kepahiang.

Teknik analisis yang digunakan dalam penelitian ini adalah teknik analisis kuantitatif, yaitu metode analisa yang menggunakan rumus statistik yang berdasarkan angka-angka dan perhitungan. Analisis data dalam penelitian ini menggunakan data panel (pooled data) yaitu gabungan dari data runtut waktu (time series) dan data silang (cross section). Kemudian Pengujian hipotesis dilakukan dengan model regresi data panel.

Untuk mengetahui pengaruh variabel bebas terhadap respon penawaran cabai alat analisis produksi digunakan alat analisis Coob-Douglas yang dikembangkan untuk melihat pengaruh dominan yaitu:

$\mathrm{Qt}_{\mathrm{i}}=\mathrm{A}+\beta_{1} \mathrm{Pct}_{\mathrm{i}}+\beta_{2} \mathrm{Qt}_{\mathrm{i}}+\beta_{3} \mathrm{At}_{\mathrm{i}}+\beta_{3} \mathrm{Pst}_{\mathrm{i}}+\mathrm{e}_{\mathrm{i}}$

$\mathrm{Qt}_{\mathrm{t}}=\mathrm{A}+\beta_{1} \mathrm{Pct}_{\mathrm{t}}+\beta_{2} \mathrm{Qt}_{\mathrm{t}-1}+\beta_{3} \mathrm{At}_{\mathrm{t}}+\beta_{3} \mathrm{Pst}_{\mathrm{t}}+\mathrm{e}_{\mathrm{t}}$

Model ekonomi tersebut kemudian ditransformasikan kedalam model regresi data panel, sehingga menjadi:

$\mathrm{Qt}_{\mathrm{it}}=\mathrm{A}+\beta_{1} \mathrm{Pct}_{\mathrm{it}}+\beta_{2} \mathrm{Qt}_{\mathrm{it}-1}+\beta_{3} \mathrm{At}_{\mathrm{it}}+\beta_{3} \mathrm{Pst}_{\mathrm{it}}+\mathrm{e}_{\mathrm{it}} \ldots(3)$

Dimana:

Qt : Jumlah produksi pada tahun $\mathrm{t}$ (ton)

Pct : Harga cabai pada tahun $\mathrm{t}(\mathrm{Rp} / \mathrm{Kg})$

$\mathrm{Qt}^{-1} \quad$ : Jumlah produksi pada tahun sebelumnya (ton)

At : Luas lahan pada tahun $\mathrm{t}(\mathrm{ha})$

Pst : Harga bawang daun pada tahun $\mathrm{t}(\mathrm{Rp} / \mathrm{Kg})$

A : Konstanta

$\beta 1-\beta 4$ : Koefisien regresi dari variabel bebas

e : eror/kesalahan pengganggu

\section{Common Effect Model}

Model Common Effect merupakan model sederhana yaitu menggabungkan seluruh data time series dengan cross section, selanjutnya dilakukan estimasi model dengan menggunakan OLS (Ordinary Least Square). Model ini menganggap bahwa intersep dan slop dari setiap variabel sama 
untuk setiap obyek observasi. Dengan kata lain, hasil regresi ini dianggap berlaku untuk semua kabupaten/kota pada semua waktu.

\section{2. $\quad$ Fixed Effect Model (FEM)}

Model data panel dengan Fixed Effects Model (FEM) mengasumsikan bahwa perbedaan mendasar antar individu dapat diakomodasikan melalui perbedaan intersepnya, namun intersep antar waktu sama (time invariant). Fixed effect maksudnya bahwa koefisien regresi (slope) tetap antar individu dan antar waktu. Intersep setiap individu merupakan parameter yang tidak diketahui dan akan diestimasi.

\section{Random Effect Model (REM)}

Random Effect Model (REM) digunakan untuk mengatasi kelemahan model efek tetap yang menggunakan dummy variable, sehingga model mengalami ketidakpastian. Penggunaan dummy variable akan mengurangi derajat bebas (degree of freedom) yang pada akhirnya akan mengurangi efisiensi dari parameter yang diestimasi. REM menggunakan residual yang diduga memiliki hubungan antar waktu dan antar individu. Sehingga REM mengasumsikan bahwa setiap individu memiliki perbedaan intersep yang merupakan variabel random.

Menurut Basuki (2016: 277), untuk memilih model yang paling tepat dalam mengelola data panel, terdapat beberapa pengujian yang dapat dilakukan, yakni:

\section{Uji Chow}

Merupakan pengujian untuk menentukan model fixed effect atau Common Effect yang paling tepat digunakan dalam mengestimasi data panel. Apabila nilai $\mathrm{F}$ hitung lebih besar dari $\mathrm{F}$ kritis maka hipotesis nol ditolak yang artinya model yang tepat untuk regresi data panel adalah model Fixed Effect. Hipotesis yang dibentuk dalam Uji Chow adalah sebagai berikut :

H0 : Common Effect Model

H1 : Fixed Effect Model

\section{Uji Hausman}

Uji ini bertujuan untuk mengetahui model yang sebaiknya dipakai, yaitu fixed effect model (FEM) atau random effect model (REM). Dalam FEM setiap obyek memiliki intersep yang berbeda-beda, akan tetapi intersep masing-masing obyek tidak berubah seiring waktu. Hal ini disebut dengan time-invariant. Sedangkan dalam REM, intersep (bersama) mewakilkan nilai rata-rata dari semua intersep (cross section) dan komponen mewakili deviasi (acak) dari intersep individual terhadap nilai rata-rata tesebut (Gujarati: 2013). Hipotesis dalam uji Hausmann sebagai berikut :

$$
\begin{aligned}
& \text { Ho : Random Effect Model } \\
& \text { Ha : Fixed Effect Model }
\end{aligned}
$$

\section{a) Analisis koefisien determinasi $\left(\mathrm{R}^{2}\right)$}

Untuk mengetahui besarnya pengaruh variabel independen yaitu harga cabai tahun t (Pct), produksi cabai tahun sebelumnya $\left(\mathrm{Qt}_{-1}\right)$, luas lahan pada tahun $\mathrm{t}(\mathrm{At})$, dan harga daun bawang pada tahun $\mathrm{t}$ (Pst) terhadap variabel dependen produksi cabai (Qt) maka digunakan analisis koefisien determinasi $\left(\mathrm{R}^{2}\right)$.

b) Pengujian F( F - Test) 
Uji hipotesis koefisien regresi yang dilakukan secara menyeluruh digunakan untuk mengetahui masing-masing variabel secara simultan mempunyai pengaruh positif atau tidak terhadap variabel dependen dengan pengujian hipotesis sebagai berikut:

Ho : $b_{\mathrm{i}}=\mathrm{b}_{\mathrm{ii}}=\mathrm{b}_{\mathrm{iii}} \leq 0$;Tidak ada pengaruh positif antara variabel independent terhadap variabel dependent

$\mathrm{H}_{1:} \mathrm{b}_{\mathrm{i}}=\mathrm{b}_{\mathrm{ii}}=\mathrm{b}_{\mathrm{iii}}>0$;Minimal ada satu variabel independent yang berpengaruh positif terhadap variabel dependent.

c) Uji t (Parsial)

Digunakan untuk mengetahui pengaruh antara variabel dependent dengan variabel dependent secara individual dengan pengujian hipotesis sebagai berikut:

Ho $: b_{i}=b_{\mathrm{ii}}=b_{\mathrm{iii}} \leq 0$; Maka tidak ada pengaruh positif antara variabel luas lahan, produksi cabai tahun sebelumnya, harga cabai tahun $t$ dan harga daun bawang daun tahun $t$ terhadap respon penawaran cabai di Kabupaten Kepahiang.

$\mathrm{H}_{1}: \mathrm{b}_{\mathrm{i}}=\mathrm{b}_{\mathrm{ii}}=\mathrm{b}_{\mathrm{iii}}>0$; Ada pengaruh positif antara variabel luas lahan, produksi cabai tahun sebelumnya, harga cabai tahun $t$ dan harga daun bawang tahun $t$ terhadap respon penawaran cabai di Kabupaten Kepahiang.

\section{HASIL DAN PEMBAHASAN}

\section{Uji Chow Test}

Taraf signifikansi $\alpha=5 \%(0.05)$

Tabel 2. Uji Chow dengan Redundant Test

Redundant Fixed Effects Tests

Pool: Data

Test cross-section fixed effects

\begin{tabular}{lrrr} 
Effects Test & \multicolumn{1}{c}{ Statistic } & d.f. & Prob. \\
\hline \hline Cross-section F & 2.876417 & $(7,108)$ & 0.0086 \\
Cross-section Chi-square & 20.514302 & 7 & 0.0046
\end{tabular}

Sumber : Olahan data menggunakan Eviews Software 9.0

Dari uji Chow Test diatas didapatkan Probabilitas $0.0086<0.05$ maka uji Chow test memilih

Fixed Effect Model (FEM) lebih baik dari pada Common Effect Model (CEM).

\section{Uji Hausman Test}

Taraf signifikansi $\alpha=5 \%(0.05)$.

Tabel 3. Uji Hausman Test

Correlated Random Effects - Hausman Test

Test cross-section random effects

\begin{tabular}{lrrr}
\hline \hline Test Summary & Chi-Sq. Statistic & Chi-Sq. d.f. & Prob. \\
\hline \hline Cross-section random & 19.900669 & 4 & 0.0005 \\
\hline \hline
\end{tabular}


Sumber : Olahan data menggunakan Eviews Software 9.0

Dari uji Hausman Test diatas didapatkan Probabilitas $0.0005<0.05$ maka uji Hausman test memilih Fixed Effect Model (FEM) lebih baik dari pada Random Effect Model (FEM)

\section{Uji Statistik Regresi}

Tabel 4. Uji Statistik Regresi (Fixed Effect Model)

Dependent Variable: Qt?

Method: Pooled Least Squares

Sample: 20042018

Included observations: 15

Cross-sections included: 8

Total pool (balanced) observations: 120

\begin{tabular}{crrrr}
\hline \hline Variable & Coefficient & Std. Error & t-Statistic & Prob. \\
\hline \hline A & -65.98460 & 24.10338 & -2.737567 & 0.0072 \\
Pct? & 0.002593 & 0.001076 & 2.409962 & 0.0176 \\
Qt 1 ? & 0.531163 & 0.057086 & 9.304592 & 0.0000 \\
At? & 4.493196 & 0.533096 & 8.428494 & 0.0000 \\
Pst? & -0.002169 & 0.003826 & -0.567002 & 0.5719 \\
Fixed Effects (Cross) & & & \\
_MK-A & 14.21006 & & & \\
_BI-A & 62.38208 & & & \\
_SM-A & 19.63449 & & & \\
_KPH-A & 6.050705 & & & \\
_KBW-A & -71.38771 & & & \\
_UJM-A & -50.61664 & & & \\
_MRG-A & 8.584303 & & & \\
_TBK-A & 11.14272 & & & \\
\hline \hline
\end{tabular}

Effects Specification

Cross-section fixed (dummy variables)

\begin{tabular}{lrlr}
\hline \hline R-squared & 0.914689 & Mean dependent var & 262.9000 \\
Adjusted R-squared & 0.906000 & S.D. dependent var & 162.0071 \\
S.E. of regression & 49.67040 & Akaike info criterion & 10.74333 \\
Sum squared resid & 266452.0 & Schwarz criterion & 11.02208 \\
Log likelihood & -632.6001 & Hannan-Quinn criter. & 10.85654 \\
F-statistic & 105.2690 & Durbin-Watson stat & 2.053307 \\
Prob(F-statistic) & 0.000000 & & \\
\hline \hline
\end{tabular}

1. Uji signifikansi Simultan (Uji Statistik F)

Hasil uji data panel dengan menggunakan Fixed Effect Model menghasilkan Prob (F-statistic) sebesar 0.000000 pada taraf signifikansi sebesar 5\% didapatkan hasil akhir F-statistik < taraf signifikansi, maka Ha diterima dan Ho ditolak atau yang berarti model variabel bebas secara bersama-sama mempengaruhi variabel Qt.

2. Uji Signifikansi (Uji T) 
Uji T dilakukan untuk menguji apakah setiap variabel independen tersebut mempengaruhi variabel dependen secara signifikan dengan mengasumsikan bahwa variabel lain bersifat tetap. Pada uji regresi model Fixed Effect diketahui bahwa setiap variabelnya memperoleh hasil sebagai berikut:

Pada variabel Pct (Harga cabai pada tahun t) diperoleh hasil Prob (F-statistic) sebesar 0.0176 dengan taraf signifikansi sebesar 5\% didapatkan hasil akhir F-statistik < taraf signifikansi, maka terima Ha dan tolak Ho atau yang berarti variabel Pct (Harga cabai pada tahun t) berpengaruh signifikan terhadap variabel Qt.

Sedangkan Pada variabel Qt.1 (produksi pada tahun sebelumnya) diperoleh hasil Prob (F-statistic) sebesar 0.0000 dengan taraf signifikansi sebesar 5\% didapatkan hasil akhir F-statistik < taraf signifikansi, maka terima $\mathrm{Ha}$ dan tolak Ho atau yang berarti variabel $\mathrm{Qt}_{-1}$ (produksi pada tahun sebelumnya) berpengaruh signifikan terhadap variabel Qt.

Sedangkan Pada variabel At (luas lahan pada tahun t) diperoleh hasil Prob (F-statistic) sebesar 0.0000 dengan taraf signifikansi sebesar 5\% didapatkan hasil akhir F-statistik < taraf signifikansi, maka terima $\mathrm{Ha}$ dan tolak $\mathrm{H}_{0}$ atau yang berarti variabel At (luas lahan pada tahun $\mathrm{t}$ ) berpengaruh signifikan terhadap variabel Qt.

Sedangkan Pada variabel Pst (harga bawang daun pada tahun t) diperoleh hasil Prob (F-statistic) sebesar 0.5719 dengan taraf signifikansi sebesar 5\% didapatkan hasil akhir F-statistik > taraf signifikansi, maka terima Ho dan tolak Ha atau yang berarti variabel Pst (harga bawang daun pada tahun t) tidak berpengaruh signifikan terhadap variabel Qt.

\section{Koefisien Determinasi $\left(\mathrm{R}^{2}\right)$}

Dari hasil regresi Fixed Effect Model diperoleh nilai (R2) sebesar 0.914689 yang artinya bahwa sebanyak $91 \%$ dimana variasi variabel independen (harga cabai pada tahun $\mathrm{t}$, produksi cabai pada tahun sebelumnya, luas lahan pada tahun $t$ dan harga bawang daun pada tahun $t$ ) memiliki tingkat kedekatan dengan variabel dependen (produksi cabai pada tahun t), sedangkan sisanya sebanyak 9\% dijelaskan oleh variabel lain diluar model.

Dari persamaan regresi model Fixed Effect Model yang ditunjukkan dalam tabel 4.9 dapat diketahui bahwa model persamaan yang tepat untuk melihat pengaruh harga cabai pada tahun t, produksi cabai pada tahun sebelumnya, luas lahan pada tahun $t$ dan harga bawang daun pada tahun t terhadap produksi cabai di Kabupaten Kepahiang dapat dijabarkan dalam persamaan sebagai berikut:

$\mathrm{Qt}_{\text {it }}=\mathrm{A}+\beta_{1} \mathrm{Pct}_{\mathrm{it}}+\beta_{2} \mathrm{Qt}_{\mathrm{it}-1}+\beta_{3} \mathrm{At}_{\mathrm{it}}+\beta_{3} \mathrm{Pst}_{\mathrm{it}}+\mathrm{e}_{\mathrm{it}}$

$\mathrm{Qt}_{\mathrm{it}}=-65.98460+0.002593 \mathrm{Pct}^{*}+0.531163 \mathrm{Qt}_{-1}{ }^{*}+4.493196 \mathrm{At}^{*}-0.002169 \mathrm{Pst}^{* *}$

Dimana :

Qt : Jumlah produksi pada tahun $\mathrm{t}$ (ton)

Pct : Harga cabai pada tahun $\mathrm{t}(\mathrm{Rp} / \mathrm{Kg})$

Qt $_{-1} \quad$ : Jumlah produksi pada tahun sebelumnya (ton)

At : Luas lahan pada tahun $\mathrm{t}(\mathrm{ha})$

Pst : Harga bawang daun pada tahun $\mathrm{t}(\mathrm{Rp} / \mathrm{Kg})$

* $\quad$ : berpengaruh secara signifikan pada $\alpha=0,05 /(5 \%)$

** berpengaruh secara signifikan pada $\alpha=0,1 /(10 \%)$

Dari hasil regresi diatas dapat diinterpretasikan sebagai pengujian koefisien regresi sebagai berikut: 
Hasil regresi diatas menunjukkan bahwa nilai konstanta sebesar -65.98460 (negatif). Hal ini menunjukkan bahwa Kabupaten Kepahiang mengalami kekurangan persediaan cabai untuk memenuhi konsumsi cabai di kabupaten tersebut (defisit), sehingga untuk memenuhi kebutuhan cabai di Kabupaten Kepahiang harus dilakukan impor dari luar Kabupaten Kepahiang.

1. Pengujian signifikansi variabel harga cabai pada tahun $t$ terhadap variabel produksi cabai pada tahun $\mathrm{t}$

Hasil regresi diatas menunjukkan koefisien regresi Harga Cabai Pada Tahun t (Pct) yaitu 0.002393 (positif) dengan nilai probabilitas $(0,0176)<$ dari tingkat signifikansi 5 persen, $(0,05)$ sehingga Harga Cabai Pada Tahun t berpengaruh nyata terhadap produksi cabai di Kabupaten Kepahiang periode 2004-2018. Adapun besaran nilai koefisien variabel Pct yaitu sebesar 0.002393 jadi dapat disimpulkan bahwa apabila Harga Cabai Pada Tahun t naik 1 rupiah maka akan meningkatkan produksi cabai sebesar 0.002393 ton, dengan asumsi variabel Pct, Qt ${ }_{-1}$, At, Pst adalah tetap.

2. Pengujian signifikansi variabel produksi cabai pada tahun sebelumnya terhadap variabel produksi cabai pada tahun $\mathrm{t}$

Hasil regresi diatas menunjukkan koefisien regresi produksi cabai pada tahun sebelumnya $\left(\mathrm{Qt}_{-1}\right)$ yaitu 0.531163 (positif) dengan nilai probabilitas $(0,0000)>$ dari tingkat signifikansi 5 persen, $(0,05)$ sehingga produksi cabai pada tahun sebelumnya $\left(\mathrm{Qt}_{-1}\right)$ berpengaruh signifikan terhadap produksi cabai di Kabupaten Kepahiang periode 2004-2018. Adapun besaran nilai koefisien variabel $\mathrm{Qt}_{-1}$ yaitu sebesar 0.531163 jadi dapat disimpulkan bahwa produksi cabai pada tahun sebelumnya naik 1 ton maka akan meningkatkan produksi cabai sebesar 0.531163 ton dengan asumsi variabel Pct, Qt ${ }_{-1}$, At, Pst adalah tetap.

3. Pengujian signifikansi variabel luas lahan pada tahun $t$ terhadap variabel produksi cabai pada tahun $\mathrm{t}$

Hasil regresi diatas menunjukkan koefisien regresi luas lahan pada tahun t (At) yaitu 4.493196 (positif) dengan nilai probabilitas $(0,0000)<$ dari tingkat signifikansi 5 persen, $(0,05)$ sehingga luas lahan pada tahun $t$ berpengaruh nyata terhadap produksi cabai di Kabupaten Kepahiang periode 2004-2018. Adapun besaran nilai koefisien variabel At yaitu sebesar 4.493196 jadi dapat disimpulkan bahwa apabila luas lahan pada tahun $\mathrm{t}$ naik 1 hektar maka akan meningkatkan produksi cabai sebesar 4.493196 ton dengan asumsi variabel Pct, Qt ${ }_{-1}$, At , Pst adalah tetap.

4. Pengujian signifikansi variabel harga bawang daun pada tahun $t$ terhadap variabel produksi cabai pada tahun $\mathrm{t}$

Hasil regresi diatas menunjukkan koefisien regresi harga bawang daun pada tahun $\mathrm{t}$ (Pst) yaitu 0.002169 (negatif) dengan nilai probabilitas $(0,5719)>$ dari tingkat signifikansi 5 persen, $(0,05)$ sehingga harga bawang daun pada tahun t tidak berpengaruh nyata terhadap produksi cabai di Kabupaten Kepahiang periode 2004-2018 namun signifikan pada a sebesar 10\%. Adapun besaran nilai koefisien variabel Pst yaitu sebesar -0.002169 jadi dapat disimpulkan bahwa apabila harga bawang daun pada tahun $\mathrm{t}$ naik 1 rupiah maka akan menurunkan produksi cabai sebesar 0.002169 ton dengan asumsi variabel Pct, $\mathrm{Qt}_{-1}$, At, Pst adalah tetap.

Dari hasil regresi model Fixed Effect pada tabel 4.9 tentang pengaruh harga cabai pada tahun t, produksi cabai pada tahun sebelumnya, luas lahan pada tahun $t$ dan harga bawang daun pada tahun t terhadap produksi cabai di Kabupaten Kepahiang dapat dijabarkan dalam persamaan sebagai berikut :

$\mathrm{Qt}_{\mathrm{MK}}=14.21006+0.002593 \mathrm{Pct}+0.531163 \mathrm{Qt}_{-1}+4.493196 \mathrm{At}-0.002169 \mathrm{Pst}$ 


$$
\begin{aligned}
& \mathrm{Qt}_{\text {BI }}=62.38208+0.002593 \mathrm{Pct}+0.531163 \mathrm{Qt}_{-1}+4.493196 \mathrm{At}-0.002169 \mathrm{Pst} \\
& \mathrm{Qt}_{\mathrm{SM}}=19.63449+0.002593 \mathrm{Pct}+0.531163 \mathrm{Qt}_{-1}+4.493196 \mathrm{At}-0.002169 \mathrm{Pst} \\
& \mathrm{Qt}_{\text {KPH }}=6.050705+0.002593 \mathrm{Pct}+0.531163 \mathrm{Qt}_{-1}+4.493196 \mathrm{At}-0.002169 \mathrm{Pst} \\
& \mathrm{Qt}_{\mathrm{KBW}}=-71.38771+0.002593 \mathrm{Pct}+0.531163 \mathrm{Qt}_{-1}+4.493196 \mathrm{At}-0.002169 \mathrm{Pst} \\
& \mathrm{Qt}_{\mathrm{UJM}}=-50.61664+0.002593 \mathrm{Pct}+0.531163 \mathrm{Qt}_{-1}+4.493196 \mathrm{At}-0.002169 \mathrm{Pst} \\
& \mathrm{Qt}_{\text {MRG }}=8.584303+0.002593 \mathrm{Pct}+0.531163 \mathrm{Qt}_{-1}+4.493196 \mathrm{At}-0.002169 \mathrm{Pst} \\
& \mathrm{Qt}_{\text {TBK }}=11.14272+0.002593 \mathrm{Pct}+0.531163 \mathrm{Qt}_{-1}+4.493196 \mathrm{At}-0.002169 \mathrm{Pst}
\end{aligned}
$$

Dari persamaan diatas, dapat dilihat bahwa nilai konstanta Kecamatan Muara Kemumu, Kecamatan Bermani Ilir, Kecamatan Seberang Musi, Kecamatan Kepahiang, Kecamatan Merigi dan Kecamatan Tebat Karai bernilai positif. Hal ini menunjukkan bahwa ketika harga cabai tahun $\mathrm{t}$, produksi cabai tahun sebelumnya, luas lahan tahun $\mathrm{t}$ dan harga bawang daun pada tahun $\mathrm{t}$ diasumsikan tetap (tidak berubah) maka jumlah produksi cabai sebesar koefisien Qt perkecamatan yang bernilai positif. Selanjutnya, nilai konstanta Kecamatan Kabawetan dan Ujan Mas bernilai negatif, ketika harga cabai tahun $t$, produksi cabai tahun sebelumnya, luas lahan tahun $t$ dan harga bawang daun pada tahun $\mathrm{t}$ diasumsikan tetap (tidak berubah) maka jumlah produksi cabai sebesar koefisien Qt perkecamatan sebesar -71.38771 dan -50.61664 dengan demikian, Kecamatan Kabawetan dan Kecamatan Ujan Mas mengalami defisit persediaan dalam memenuhi konsumsi cabai.

\section{Pengaruh Harga Cabai Pada Tahun t Terhadap Produksi Cabai}

Dari hasil penelitian uji signifikansi ini didapatkan bahwa sebanyak 3 variabel berpengaruh signifikan terhadap variabel Qt yaitu Pct (harga cabai pada tahun t), $\mathrm{Qt}_{-1}$ (produksi cabai pada tahun sebelumnya) dan At (luas lahan pada tahun t) selain itu terdapat variabel Pst (harga bawang daun pada tahun $t$ ) tidak berpengaruh secara signifikan terhadap variabel Qt.

Pengujian statistik dalam penelitian ini, variabel Harga Cabai Pada Tahun t memiliki pengaruh yang positif dan signifikan terhadap pertumbuhan ekonomi. Hasil ini sama dengan hipotesis yang telah diajukan pada pembahasan sebelumnya, bahwa variabel Harga Cabai Pada Tahun $t$ berpengaruh positif dan signifikan terhadap produksi cabai merah keriting di Kabupaten Kepahiang. Hal ini diperlihatkan oleh hasil regresi yang diperoleh bahwa nilai koefisien regresi pada variabel harga cabai pada tahun t sebesar 0.002593 dengan nilai probabiliti sebesar 0.0176 . Dengan tingkat keyakinan 95\% atau $\alpha$ sebesar 0,05. meningkatnya Harga Cabai Pada Tahun t pada suatu daerah , juga ikut mendorong terjadinya peningkatan produksi cabai di daerah tersebut. Hal ini memperkuat anggapan bahwa peningkatan Harga Cabai Pada Tahun t terutama pada tahun 2004 - 2018 memberikan kontribusi yang meyakinkan terhadap produksi cabai merah keriting.

\section{Pengaruh Produksi Pada Tahun Sebelumnya Terhadap Produksi Cabai}

Dari hasil regresi, dapat dilihat nilai koefisien pada variabel produksi pada tahun sebelumnya sebesar 0.531163 dengan niali probabiliti sebesar 0.0000, dengan tingkat keyakinan sebesar $95 \%$ atau $\alpha$ sebesar 0.05. Nilai tersebut berarti bahwa, variabel produksi pada tahun sebelumnya berpengaruh positif dan signifikan terhadap produksi cabai di Kabupaten Kepahiang. Hasil ini menunjukkan jika terjadi kenaikan produksi cabai pada tahun sebelumnya sebesar satu ton, maka akan menaikkan jumlah produksi cabai di Kabupaten Kepahiang sebesar 0.531163 ton.

Jumlah produksi cabai merah keriting memberikan pengaruh yang besar pada penawaran cabai merah keriting di Kabupaten Kepahiang. Hal tersebut sesuai dengan teori dimana penawaran dipengaruhi oleh harga produk dan jumlah produksi. Semakin tinggi jumlah produksi cabai dapat meningkatkan penawaran cabai di Kabupaten Kepahiang. Demikian pula jika jumlah produksi menurun maka penawaran cabai merah keriting di Kabupaten Kepahiang juga ikut menurun. 


\section{Pengaruh Luas Lahan Pada Tahun T Terhadap Produksi Cabai}

Dari hasil regresi, dapat dilihat nilai koefisien pada variabel luas lahan pada tahun $\mathrm{t}$ sebesar 4.493196 dengan niali probabiliti sebesar 0.0000 , dengan tingkat keyakinan sebesar $95 \%$ atau $\alpha$ sebesar 0.05 . Nilai tersebut berarti bahwa, variabel luas lahan pada tahun $t$ berpengaruh positif dan signifikan terhadap produksi cabai di Kabupaten Kepahiang. Hasil ini menunjukkan jika terjadi kenaikan luas lahan pada tahun t sebesar satu hektar, maka akan menaikkan jumlah produksi cabai di Kabupaten Kepahiang sebesar 4.493196 ton.

\section{Pengaruh Harga Bawang Daun Pada Tahun t Terhadap Produksi Cabai}

Dari hasil regresi, dapat dilihat nilai koefisien pada variabel harga bawang daun pada tahun $\mathrm{t}$ sebesar -0.002169 dengan niali probabiliti sebesar 0.5719 , dengan tingkat keyakinan sebesar $95 \%$ atau $\alpha$ sebesar 0.05 . Nilai tersebut berarti bahwa, variabel harga bawang daun pada tahun t tidak berpengaruh positif dan tidak signifikan terhadap produksi cabai di Kabupaten Kepahiang pada $\alpha=$ $5 \%$ namun berpengaruh signifikan pada $\alpha=10 \%$. Hasil ini menunjukkan jika terjadi kenaikan harga bawang daun pada tahun t sebesar satu rupiah, maka akan menurunkan jumlah produksi cabai di Kabupaten Kepahiang sebesar 0.002169 ton.

Harga barang substitusi dalam hal ini adalah bawang daun memiliki pengaruh negatif terhadap produksi cabai merah keriting di Kabupaten Kepahiang. Meskipun pengaruhnya tidak signifikan namun perubahan harga bawang daun juga ikut mempengaruhi produksi cabai merah keriting di Kabupaten Kepahiang pada $\alpha=10 \%$, dengan kata lain jika harga bawang daun naik maka akan mengurangi jumlah produksi cabai merah keriting.

\section{KESIMPULAN DAN SARAN}

Berdasarkan hasil penelitian dan pembahasan penawaran cabai di Kabupaten Kepahiang yang berkaitan dengan pengaruh harga cabai tahun t, produksi cabai tahun sebelumnya, luas lahan tahun $\mathrm{t}$ dan harga barang substitusi tahun $\mathrm{t}$, maka dapat ditarik beberapa kesimpulan sebagai berikut :

1. Hasil analisis data menunjukkan bahwa variabel harga cabai pada tahun t, produksi cabai pada tahun sebelumnya, luas lahan pada tahun $t$ dan harga bawang daun secara simultan atau bersama-sama berpengaruh signifikan terhadap produksi cabai di Kabupaten Kepahiang.

2. Secara parsial, harga cabai pada tahun t, produksi cabai tahun sebelumnya, luas lahan tahun $t$ berpengaruh positif dan signifikan terhadap produksi cabai di Kabupaten Kepahiang dan harga bawang daun pada tahun $t$ berpengaruh negatif dan tidak signifikan pada $\alpha=5 \%$ namun signifikan pada $\alpha=10 \%$ terhadap produksi cabai di Kabupaten Kepahiang.

3. Dari hasil regresi menunjukkan bahwa Kabupaten Kepahiang mengalami defisit persediaan cabai untuk memenuhi kebutuhan konsumsi cabai masyarakat Kabupaten Kepahiang hal ini diperlihatkan dari konstanta bernilai negatif.

Berdasarkan hasil penelitian dan kesimpulan maka dapat disusun beberapa saran yang dapat di berikan berkaitan dengan penawaran cabai di Kabupaten Kepahiang sebagai berikut:

1. Areal panen merupakan faktor yang responsif terhadap penawaran cabai merah keriting di Kabupaten Kepahiang, sehingga saran dari hasil penelitian ini adalah petani dapat melakukan intersifikasi pertanian melalui beberapa cara diantaranya ialah dengan cara pengolahan tanah yang baik, pemilihan bibit unggul, pemupukan, pemberantasan hama dan penyakit tanaman. agar produksi cabai merah keting yang dihasilkan meningkat, serta penerapan pola tanam yang baik dalam budidaya cabai merah keriting dalam rangka meningkatkan penawaran cabai merah keriting di Kabupaten Kepahiang. 
2. Untuk meningkatkan produksi cabai merah keriting di Kabupaten Kepahiang, sebaiknya petani memperhatikan kondisi lahan dan perawatan tanaman agar dapat memberikan hasil produksi yang maksimal.

3. Diharapkan pemerintah Kabupaten Kepahiang lebih memperhatikan sektor pertanian dan pembudidayaanya, khususnya hortikultura seperti cabai merah keriting. Mengadakan sosialisasi dan pelatihan untuk meningkatkan produksi dan mengurangi gagal panen secara efektif dan efisien, serta membantu mengembangkan pasar hortikultura.

\section{DAFTAR PUSTAKA}

Agromedia. 2010. Panduan Lengkap Budidaya Dan Bisnis Cabai. Jakarta: PT Agromedia Pustaka. Agromedia, Redaksi. 2008. Buku Pintas Tanaman Obat. Jakarta Selatan: PT Agromedia Pustaka

Ariyani, V.T. 2016. Analisis Penawaran Cabai Besar Di Kabupaten Purworejo. Universitas Muhammadiyah Purworejo

Badan Pusat Statistik. 2017. Provinsi Bengkulu Dalam Angka. Bengkulu: Badan Pusat Statistik.

Badan Pusat Statistik. (Berbagai Tahun). Kabupaten Kepahiang Dalam Angka. Kepahiang: Badan Pusat Statistik.

Basuki, Agus Tri dan Nano Prawoto. 2016. Analisis Regresi Dalam Penelitian Ekonomi dan Bisnis. Depok: PT Raja Grafindo Persada

Bina Karya Tani. 2009. Pedoman Bertanam Cabai. Bandung: Ghalia Indonesia

Daniel, Moehar. 2004. Pengantar Ekonomi Pertanian. Jakarta: Bumi Aksara

Dinas Ketahanan Pangan Kabupaten Kepahiang. 2018. Hasil Survei Lapangan. Kepahiang: Dinas Ketahanan Pangan Kabupaten Kepahiang.

Firdaus, M. 2008. Manajemen Agribisnis. Jakarta: Bumi Aksara.

Gujarati. 2013. Dasar-Dasar Ekonometrika. Jakarta: Erlangga.

Hanafie, R. 2010. Pengantar Ekonomi Pertanian. Yogyakarta: Andi Offset.

Haryati. 2007. Pengantar Ekonomi Mikro. Yogyakarta: Depublish

Kusandriani. 1996. Bertani Tanaman Cabai Merah. Bandung: Balai Penelitian Tanaman Sayuran.

Kusandriani. 1996. Pemuliaan Tanaman Cabai. Universitas Gajah Mada

Kotler dan Amstrong. 1999. TeoriEkonomi Makro Intermediate. Jakarta: Raja Grafindo Persada.

Mankiw, N.G. 2000. Pengantar Ekonomi Jilid 1. Jakarta: Erlangga.

Rahardja, P dan Manurung, M. 2010. Teori Ekonomi Mikro, Suatui Pengantar. Jakarta: FE-UI.

Soekartawi. 1993. Prinsip Dasar Ekonomi Pertanian. Jakarta: PT Raja Grafindo Persada

Sriyadi. 2001. Bisnis Pengantar Ekonomi Perusahaan Modern. Semarang: IKIP Semarang Press.

Sukirno, S. 2006. Pengantar Teori Mikroekonomi, Edisi Ketiga. Jakarta: PT Raja Grafindo

Susanti, N. 2006. Peramalan Permintaan Cabai Merah (Studi Kasus Pasar Induk Kramat Jati, DKI Jakarta). Bogor: Program Studi Manajemen Agribisnis, Fakultas Pertanian, Institut Pertanian Bogor.

Swastha. 2001. Manajemen Pemasaran Modern. Yogyakarta: BPFE

Unila. 2011. Ketinggian Tempat Dan Pertumbuhan Tanaman. Universitas Negeri Lampung 